\section{Til ettertanke}

Helander E.

\section{Children and violence}

The world of the defenceless. 334 s, tab, ill. New York, NY: Palgrave Macmillan, 2008. Pris GBP 60

ISBN 978-0-230-57394-9

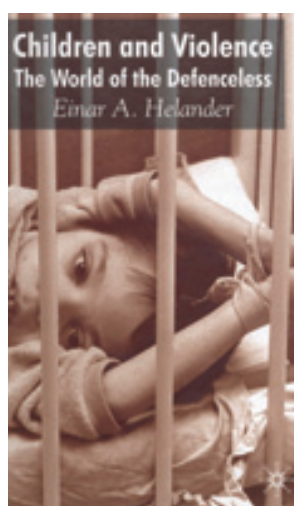

Overgrep mot og misbruk av barn har foregått og foregår fortsatt innen alle kulturelle, religiøse og økonomiske grupperinger, men dette ble ikke erkjent av den medisinske verden før i 1960årene. Nylig har også norske aviser hatt oppslag om omfanget og om tendensen til underrapportering og -prioritering. Med dette som bakgrunn er denne solide faglige og empiriske fremstillingen av situasjonen for verdens barn, deres forsvarsløshet og fysiske og mentale senskader, helt betimelig. Dette angår ikke bare leger, det angår alle som arbeider med barnas beste for øye.

Forfatteren er svensk, lege fra 1953. Han bygger på sine omfattende praktiske og teoretisk kunnskaper og erfaringer fra 30 års arbeid med rehabilitering av funksjonshemmede i mange land og fra arbeid i lokale og internasjonale organisasjoner (bl.a. WHO og FN).

I seks kapitler redegjøres det for problemet i hele dets bredde: De foreldreløse og/eller institusjonaliserte barnas situasjon (med skremmende bilder fra ulike institusjoner), nevrobiologiske og andre følger av omsorgssvikt og voldens årsaker - og ikke minst er det en beskrivelse av tjenesteoppbygging og gode retningslinjer for forebyggende intervensjoner. Det er mer enn 600 referanser til rapporter, artikler, internasjonale konvensjoner og programmer for å bidra til endring. Likevel er situasjonen fortsatt slik at mer enn en milliard barn i utviklingsland opplever omsorgssvikt relatert til fattigdom $i$ en grad som får alvorlige følger for deres videre utvikling og funksjon. Fra utviklede land er det bl.a. dokumentert at underholdningsindustrien, ikke minst TV og spesielt videospill, er med på å aktivere negativ og voldelig atferd.
Dette er kort sagt en faglig overbevisende fremstilling av et emne som vi alle bør sette oss inn i, enten vi er leger, foreldre eller besteforeldre. Ikke minst kan vi tenke over hvordan vi kan bidra til en mindre voldelig utvikling i vårt eget samfunn.

Inger Helene Vandvik

Slependen

\section{Alternativet til etterpåklokskap}

Gerstein M.

\section{Flirting with disaster}

Why accidents are rarely accidental. 340 s, tab, ill. New York: Sterling Publishing, 2008.

Pris USD 17

ISBN 978-1-4027-6108-2

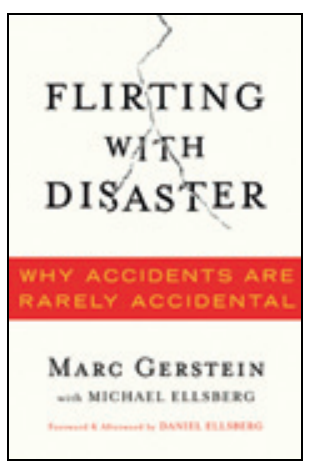

Det sies at erfaring er noe man først har oppnådd når det er for sent. Likevel er det en grunnleggende forutsetning for vår tids tro på avviksregistrering og årsaksanalyse i situasjoner som enten har holdt på å gå forferdelig galt eller som faktisk

har gått ille at det er mulig å lære av dette og på den måten unngå liknende katastrofer i fremtiden.

Dette er en ganske kort og spennende gjennomgang av åtte katastrofer som de fleste av oss har hørt om. De spenner fra den manglende forståelse av faren for at New Orleans skulle rammes av en dødbringende flom via romfergene Columbias og Challengers siste turer til Mercks kyniske markedsføring av Vioxx og revisjonsfirmaet Arthur Andersens endelikt. Forfatteren analyserer hver historie ut fra et ganske spennende perspektiv og underbygger sine synspunkter med mange og gode referanser.

Flirting with disaster anbefales kolleger - både de som måtte interessere seg for risikostyring og ikke minst de som synes at maset om avviksmeldinger ikke har noe for seg. Det finnes interessant nok også analyser av et par nyere hendelser på bokens hjemmeside (1).
Både forfatteren og Daniel Ellsberg (mannen bak The Pentagon Papers) poengterer i for- og etterord hvor viktig det er å utnytte fagfolkene i en organisasjon og hele tiden være klar over de verdier og etiske valg man står overfor. Kun ved å forstå risikobegrepet og farene ved de prosessene man driver med samt kontinuerlig lytte til innspill og monitorere virksomheten kan man unngå mange av de katastrofer som lurer i fremtiden. Og dem er det nok av, også innen helsesektoren!

\section{Guttorm Brattebø}

Akuttmedisinsk seksjon

Kirurgisk serviceklinikk

Haukeland universitetssykehus

Litteratur

1. www.flirtingwithdisaster.net (18.12.2008).

\section{Helse og sosial posisjon}

\section{Elstad Jl.}

\section{Utdanning og helseulikheter}

Problemstillinger og forskningsfunn. $148 \mathrm{~s}$, tab, ill. Oslo: Helsedirektoratet, 2008. Gratis IS-1573

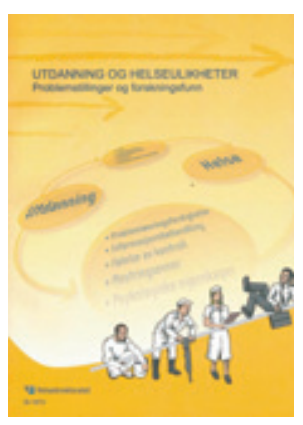

Helsedirektoratets ekspertgruppe om sosiale ulikheter $\mathrm{i}$ helse har utgitt et hefte før, Gradientutformingen, som gir en svært kort innføring i temaet. Den foreliggende boken er en grundigere oversikt over sosial posisjon og en rekke helsemål. Den er skrevet av et medlem i gruppen, Jon Ivar Elstad, sosiolog ved NOVA (Norsk institutt for forskning om oppvekst, velferd og aldring). Han har forsket på dette temaet i mange år og viser her et solid grep om teori, forskningsresultater og metoder på feltet.

Utdanning er det målet han har valgt for sosial posisjon. Det er et vellykket grep, for i svært mange norske og andre vestlige studier har man brukt dette målet, som har god validitet både for unge voksne og senere i livet når det gjelder plassering $i$ den sosiale lagdelingen.

Helsemålene er mange, og Elstad viser 